DOI: https://doi.org/10.47405/mjssh.v6i9.1018

\begin{tabular}{|c|c|}
\hline tistis & Malaysian Journal of Social Sciences and Humanities (MJSSH) \\
\hline Malaysian Journal of & Volume 6, Issue 9, September 2021 \\
\hline (MJ-sSH) & e-ISSN : 2504-8562 \\
\hline & $\begin{array}{l}\text { Journal home page: } \\
\text { www.msocialsciences.com }\end{array}$ \\
\hline
\end{tabular}

\title{
Business Feasibility Towards Clothing Convection: A Case Study of Raiment
}

\author{
Nurfaiz Firdauzi Ilyas ${ }^{1}$, Atika Irawan ${ }^{1}$ \\ ${ }^{1}$ School of Business and Management, Bandung Institute of Technology, Indonesia \\ Correspondence: Nurfaiz Firdauzi Ilyas (nurfaiz_firdauzi@sbm-itb.ac.id)
}

\begin{abstract}
Raiment is an MSME company engaged in clothing convection which aims to provide convenience through online sales and ordering. However, currently it still does not have its own production house and is still outsourcing by collaborating with other companies in its production, as Raiment's business is considered not to meet expectations from stagnant growth and unstable revenue. Raiment wants to open its own production house so that it does not depend on other companies in its production and can maximize profits. The purpose of this study was to determine the financial feasibility of Raiment to open its own production house. This study uses a qualitative approach through interviews and company historical data as primary data, as well as secondary data from literature reviews, journals, and books. In this study, an analysis of the industry was also carried out through PESTEL analysis and porter's five forces, as well as about the company through SWOT and financial reports. To analyse the problems that exist in the company, a fishbone diagram is used. And to analyse the financial feasibility of the company's strategy to open its own production house using the payback period, net present value, and internal rate of return. The investment in opening a production house will be financed by equity of Rp66,500,000. The results show that Raiment is feasible to open its own production house, with a payback period of 1.4 years, a positive NPV of IDR 235,260,441, and an IRR of 36.08\% which is more than the cost of capital of $4.18 \%$.
\end{abstract}

Keywords: clothing convection, financial feasibility, capital budgeting

\section{Introduction}

In recent years, the mutual relationship between culture and economics has stabilized. The role of creativity became a subject of discussion, and nowadays creative industries play a critical role for global business as a faster-developing sector and a source of economic growth, so creative industries play important roles in global economics (Dunska \& Marcinkevica, 2017). As one of the sectors in creative industries, fashion has always been a fascinating topic to debate; people wear shirts, jeans, shoes, and accessories to complete their style. Fashion is one of the most in-demand businesses because everyone owns more than one pair of clothes. In general, the fashion industry is a dynamic industry that makes it difficult to precisely predict demand because each consumer's style and model has a varied need (Sugih \& Soekarno, 2014).

Because a fashion business can exist based on the various demands of its people, the number of fashion industry players grows every year. Aside from that, the global fashion business industries performed excellently; this assertion is supported by the fact that the sales growth of the fashion industry has 
increased by 3.5 to 4.5 percent since 2017 (McKinsey Company, 2018). In this pandemic situation, millions of people's lives and livelihoods have been affected, as well as international trade, travel, the economy, and consumer behavior. In the Later Recovery scenario, the hard environment created by the unprecedented events of 2020 will last into 2021, with global fashion sales predicted to be $15 \%$ lower than in 2019. Global fashion sales would not fully rebound to pre-crisis levels until the third quarter of 2022 at the earliest. During the pandemic, many firms went online for the first time, and fans embraced digital innovations like livestreaming, customer service video chat, and social buying. Fashion brands must optimize the online experience and channel mix while finding appealing methods to integrate the human touch as online penetration increases and shoppers seek ever-more sophisticated digital interactions (McKinsey Company, 2021).

Convection of clothing, as one of the creative industries, has an important role in the national economy in many countries, including Indonesia. In many countries, especially in Indonesia, the creative industry has become a leading component of economic growth, employment, and innovation (Hidayat \& Asmara, 2017). According to the roadmap of Making Indonesia 4.0 (Kementerian Perindustrian Republik Indonesia, 2018), the development of the textile and clothing industry will become a priority that will be included in the top five priority of manufacturing sectors in the industrial era 4.0. In 2019, the growth of the textile and clothing industry is 8.73 percent higher and increasing the rivalry competition among the industry. In Making Indonesia 4.0, it involved one of the national initiatives to increase the development of Indonesia's manufacturing sector, and the initiative is linked to empowering Micro, Small and Medium Enterprises (MSMEs). The program of Making Indonesia 4.0 designed in 2018, the implementation of Making Indonesia 4.0 is started from 2019 to 2030. Making Indonesia 4.0 divided into 3 periods, from 2019 to 2021, from 2022 to 2025, and 2026 to 2030. It will be evaluated periodically to make decision intersectoral to improve the progress of the program.

In Indonesia, Micro, Small and Medium Enterprises (MSMEs) play a significant role in the economy. MSMEs have a proportion of $99.99 \%$ of the total numbers of market players in Indonesia, or up to 56.54 million units. Based on the asset and revenue, MSMEs categorized into three groups, Micro-business with assets no more than IDR 50 million and revenue of no more than IDR 300 million, small business with assets more than IDR 50 million to IDR 500 million and revenue more than IDR 300 million to IDR 2.5 billion, Medium-sized business with assets more than IDR 500 million to IDR 10 billion and revenue more than IDR 2.5 million to IDR 50 billion (Bank Indonesia, 2015). MSME are socially and economically important because they comprise most businesses and hence support entrepreneurship and innovation by providing self-employment. All types of businesses require sufficient finances to meet both the fixed capital and working capital requirements. Finance is one of the crucial challenges for MSME growth and development (Zakkariya \& Nishanth, 2014).

Bandung, as one of Indonesia's creative cities, has made a significant contribution to the country's creative industry's development. Bandung's creative industry is expected to expand by up to $30 \%$ by the end of 2018. Bandung thus becomes a barometer of the creative industry, particularly in the convection industry, because of this fact. Convection company ranks 5th out of 28 processing industry goods with high potential and competitiveness, according to the SE2018 listing. Aside from that, Bandung has the most clothing convection companies, with 10,109 establishments (Adwiyah et al., 2020).

Raiment is a MSMEs company engaged in the convection industry that produces apparel and wants to give ease through online ordering and selling. Based on the promising market and growth of the fashion industry, Raiment started its business by offering solutions that make it easier for customers to deal with the problems that exist in clothing convection, but currently still haven't had the company's own production machine. Raiment currently outsources its production and targets to buy production machines with the profit that the company gains from current business model. However, after running the business, the clothing convection of Raiment did not meet the expectations of the industry. The business has still had stagnant growth and unstable revenue or even decreasing revenue. Raiment is still not proper in running its business, from the lack experience of founders that make our knowledge from business and the industry haven't good enough, so we did not have the financial planning for our business and its influence how the business run without target sales and finally have low financial performance. It makes the business don't meet the growth expectations of the industry. One of the strategies that Raiment 
decided is to establish the company's own production to increase the revenue and profit, because with outsourcing the production process, we depend on other company's prices and can't maximize the margin because we have to conciliate the price of the market, and to own company's own production house, Raiment can manage the production and didn't have to be depends on other company in state of production quality and time. So, a feasibility study can help Raiment decide whether the strategy is feasible or not.

\section{Literature Review}

\section{Financial Statement}

A financial statement is one of the most important tools for businesses, and the information included in it is utilized to make decisions. Financial statements allow stakeholders to use readily available financial data to gain a better understanding of and control over their company (Auken \& Carraher, 2013). The income statement, balance sheet, statement of stockholders' equity, and statement of cash flows are the four main financial statements required (Gitman \& Zutter, 2015, p.107).

\section{Income Statement}

The income statement is a financial statement that summarizes the company's operating performance for a specific time span. Income statements for a one-year duration ending on a specific date are the most common (Gitman \& Zutter, 2015, p.107).

\section{Balance Sheet}

The balance sheet is a summary statement of the company's financial situation at a certain point in time. The balance sheet compares the firm's assets to its debt or equity funding (Gitman \& Zutter, 2015, p.107).

\section{Statement of Cash Flow}

The cash flow statement is a rundown of the cash flows for the time span under consideration. The statement summarizes the firm's operating, acquisition, and funding cash flows, as well as reconciles them to shifts in cash and marketable securities over time (Gitman \& Zutter, 2015, p.113).

\section{Cash Flow Forecasting}

The approaches used to investigate the dynamics of market cash flows from a historical and forwardlooking viewpoint are referred to as cash flow forecasting. Cash flow forecasting is required for SMEs to enter the expansion phase by calculating additional capital (Fight, 2006).

\section{Capital Budgeting}

The method of assessing and choosing long-term assets that are compatible with the firm's objective of optimizing owners' wealth is known as capital budgeting (Gitman \& Zutter, 2015, p.442).

\section{Internal Rate of Return}

The internal rate of return (IRR) is a discount rate that equates an investment opportunity's net present value (NPV) to zero dollars (because the present value of cash inflows equals the initial investment). It is the rate of return that a company would get if it invested in a project and collects the specified cash inflows (Gitman \& Zutter, 2015, p.453).

\section{Net Present Value}


Net present value is the approach used by most large corporations to assess investment ventures. The net present value of a project is calculated by subtracting the original expenditure from the present value of the project's cash inflows discounted at the firm's cost of capital (Gitman \& Zutter, 2015, p.449).

\section{Payback Period}

The payback period method is often used by small and medium-sized businesses to assess proposed investments. The payback period is the amount of time it takes for a company to recoup its initial investment in a project using cash inflows (Gitman \& Zutter, 2015, p.444).

\section{Business Feasibility}

Feasibility studies assist entrepreneurs in determining if their business concept is feasible in light of the domain conditions (Amanor-Boadu, 2003).

Figure 1: Conceptual Framework

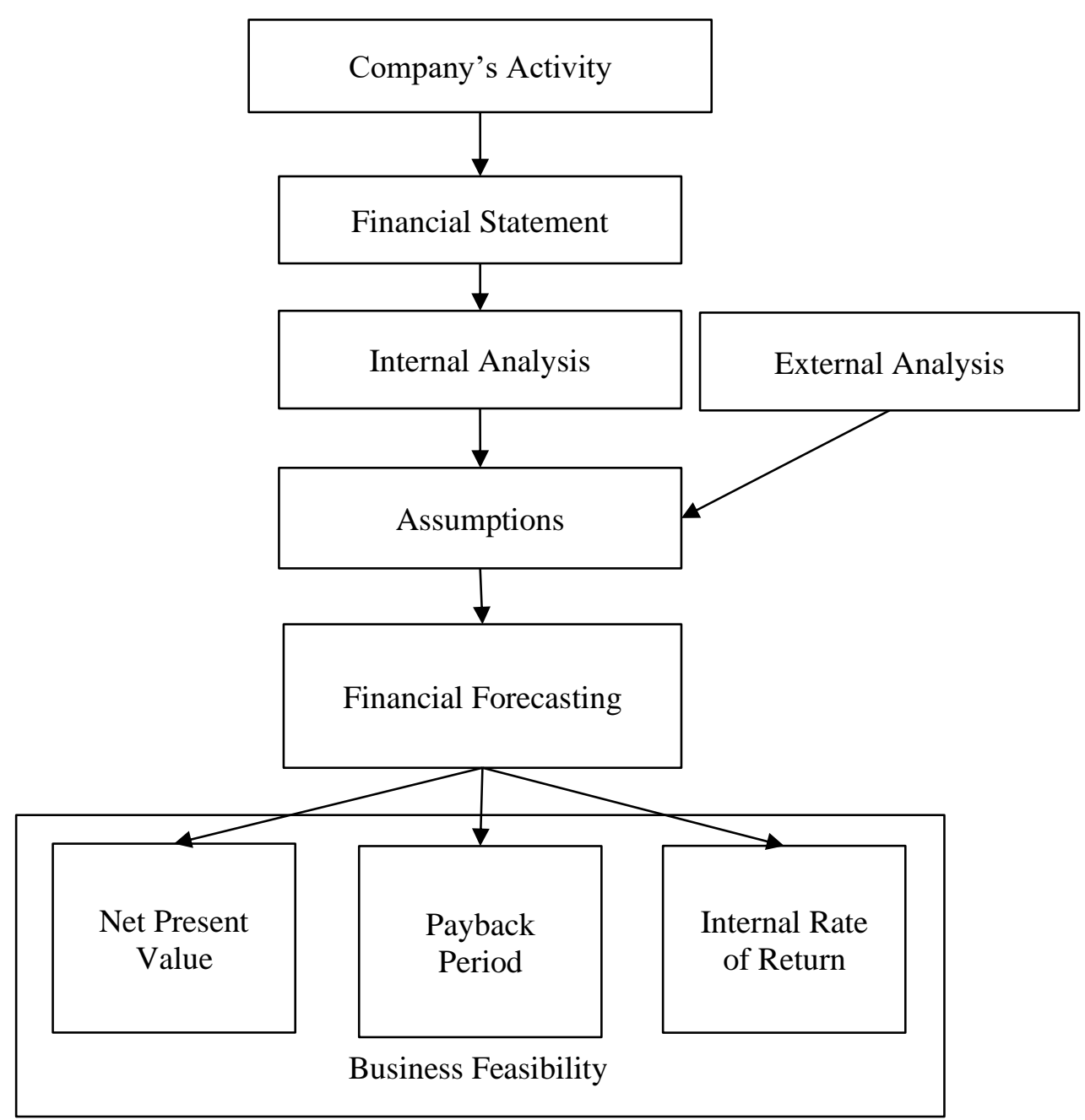




\section{Methodology}

\section{Problem Identification}

The researcher identifies the current business condition and the problem in the company.

\section{Theoretical Foundation}

A theoretical framework is needed as a source of information that will be used in problem-solving. Theoretical foundations used in this research include financial success theories as well as root cause theory.

\section{Data Collection}

The researcher collects the data through primary and secondary data.

\section{Primary Data}

The researcher will collect data from the Raiment company's financial data, as well as data from surveys and interviews with businesses in the same industry as the Raiment company. Primary data are data obtained specifically for a research issue using methods related to the problem (Hox \& Boeije, 2005).

\section{Secondary Data}

The researcher may gather information from relevant books, literature reviews, journals, and papers. Secondary data is made up of knowledge about objects that have been observed and whose properties have been coded into variables with several possible values (Hox \& Boeije, 2005).

\section{Internal Analysis}

In the internal analysis, the researcher will analyze the internal aspect of the business. In this research, the researcher will conduct internal analysis using SWOT analysis, analysis of historical financial statements of the company, technology readiness level, and root cause analysis using fishbone diagram.

\section{External Analysis}

In the external analysis, the researcher will analyze the external aspect of the business. The competitor and business in the same industry will be analyzed. The researcher also uses PESTEL analysis to analyses the macro environment of the industry, and porter's five forces to analyses the microenvironment of the industry.

\section{Data Analysis}

The data that is collected by the researcher will be analyzed through forecasting and feasibility analysis.

\section{Feasibility Analysis}

Financial feasibility is a method of determining the viability of proposed initiatives that focuses on the financial aspects of the research. Net present value, internal rate of return, and payback period are the three most widely used models to evaluate it (Miller et al., 2017). 
Figure 2: Research Design

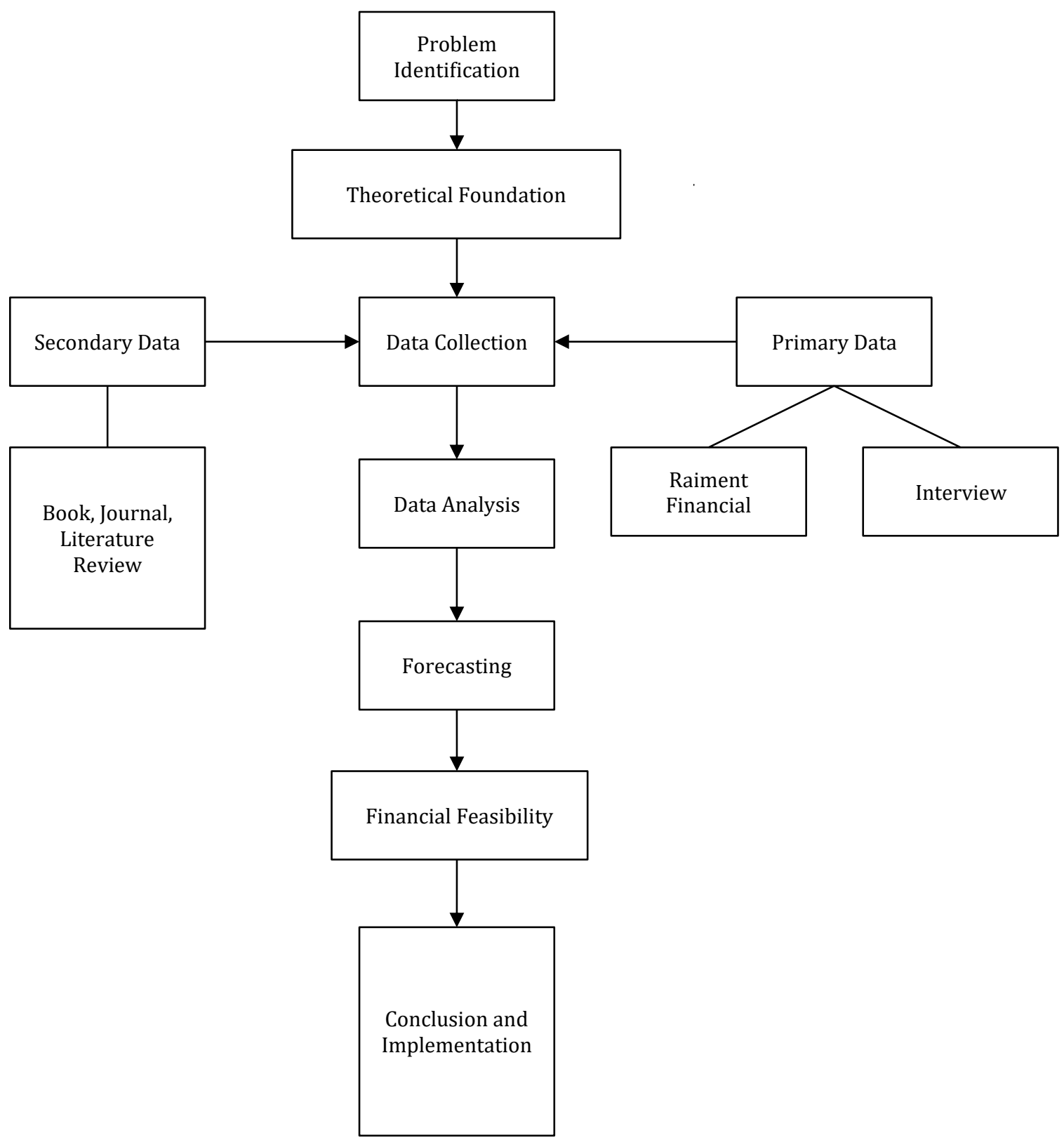

\section{Result}

\section{PESTEL Analysis}

\section{Political}

Raiment company is included in the textile and clothing industry. The textile and clothing industry is one of the priority sectors in the Making Indonesia 4.0 program which is important to continue to be developed based on (Kementerian Perindustrian Republik Indonesia, 2018). The Ministry of Industry has designed Making Indonesia 4.0 as an integrated roadmap to implement several strategies in entering the industry 4.0 era. In the fourth industrial revolution, it became a big leap for the industrial sector, where information and communication technology were fully utilized. Not only in the production process, but also throughout the industrial value chain, giving birth to a new business model on a digital basis to achieve high efficiency and better product quality. Therefore, the national industrial sector needs 
a lot of improvement, especially in the aspect of mastering technology which is the key determinant of competitiveness in the industry 4.0 era. There are five main technologies that support the development of the industry 4.0 system, namely the Internet of Things, Artificial Intelligence, Human-Machine Interface, robotic and sensor technology, and 3D Printing technology. By implementing Industry 4.0, the Minister of Industry is targeting that the big national aspirations can be achieved. In general, these aspirations are to bring Indonesia into the top 10 economies in 2030. One of Indonesia's strategies for entering Industry 4.0 is to prepare five manufacturing sectors that will serve as pilots to strengthen the fundamental structure of the country's industry. The five sectors are the Food and Beverage Industry, Automotive Industry, Electronic Industry, Chemical Industry, and Textile Industry. the government has some strategies to implement Making Indonesia 4.0, these include improving the flow of goods and materials to strengthen local production in the upstream and midstream sectors, optimizing industrial zone policies by aligning roadmaps in the industrial sector, accommodating industrial capabilities, and building digital infrastructure to encourage technology adoption, as well as attracting foreign investment.

\section{Economic}

The global fashion business industries performed excellently; this assertion is supported by the fact that the sales growth of the fashion industry has increased by 3.5 to 4.5 percent since 2017 (McKinsey Company, 2018). As one of the 16 creative industry groups, the fashion industry also plays an important role in the national economy. In fact, this sector continued to grow positively in the 2017-2019 range. In 2017 , the growth was recorded at $3.83 \%$. Then, it rose to $8.73 \%$ in 2018 and to $15.35 \%$ in 2019. In 2020, Textile and apparel industry slumped during the Covid-19 pandemic. The Ministry of Industry noted the growth of the textile and apparel industry was minus $8.8 \%$ on an annual basis (YoY) in 2020 (Kementerian Perindustrian Republik Indonesia, 2018).

\section{Social}

During the pandemic, many firms went online for the first time, and fans embraced digital innovations like livestreaming, customer service video chat, and social buying. Fashion brands must optimize the online experience and channel mix while finding appealing methods to integrate the human touch as online penetration increases and shoppers seek ever-more sophisticated digital interactions (McKinsey Company, 2021). In the national fashion industry, one of the causes of the contraction last year was declining demand due to changes in people's consumption patterns. According to the Central Statistics Agency (BPS) in June 2020, public consumption for health increased by $73.3 \%$ and food ingredients by $65.8 \%$ compared to before the pandemic. On the other hand, other needs tend to decrease.

\section{Technological}

We are currently entering an era called industry 4.0, which is a period of fundamentally changing human ways of life and work systems. Where computers and all automation are now also combined with cyber digitalization. For almost two years, the world has been facing a pandemic that initially caused various business fields to experience shocks. Starting from the implementation of work from home to social restrictions that change people's habits. Which affects the clothing convection industry to further develop on the technology side. Starting from the production sector, the company's internal system, and also marketing. Current manufacturing technology allows the convection industry to be more productive by digitizing existing processes. The result of manufacturing technology is that production is much faster, there is less waste, and the time to market is shorter. Innovations in the production sector are sewing machine innovation, $3 \mathrm{~d}$ printing, and digital textile printing. And also in the marketing sector, which uses websites and social media as a means of promotion and branding of the company.

\section{Environmental}

According to the Elucidation of Article 21 paragraph (1) of the Industrial Law, industrial businesses operating are required to pay attention to the balance and preservation of natural resources used in their industrial processes, as well as to avoid environmental damage and pollution as a result of their business 
and industrial processes. Soil, water, and air pollution, as well as noise from industrial activities, can have negative consequences such as disruption, damage, and danger to the safety and health of the surrounding population. Based on the (European Parliament, 2021), water pollution, greenhouse gas emissions, and landfill waste are all caused by clothing, footwear, and household textiles. The environmental damage that might be affected comes from the waste of the industrial process, such as water pollution that comes from the use of chemical substances in the production process, the fashion industry is projected to be responsible for $10 \%$ of global carbon emissions, and clothing waste from the production process that must be disposed of in landfills. In maintaining the environment damage from the production process, we must limit the use of dangerous substances, reduce water, and air pollution, and implement a good waste management.

\section{Legal}

Based on (Fitriani, 2017) the company as a vehicle for economic development is regulated in the Civil Code, the Commercial Code, and statutory regulations. In carrying out business activities within the legal framework of business in Indonesia, there are three types of business entities, namely private business entities, state-owned enterprises, and cooperatives. What is said by a business entity or company according to Article 1 of Law Number 3 of 1982 concerning Compulsory Company Registration is any form of business that runs every type of business that is permanent and continuous, and which is established, works, and is domiciled within the territory of the Republic of Indonesia, for the purpose of making a profit. The implementation of Risk-Based Business Licensing through the Online Single Submission System (OSS) is the implementation of Law Number 11 of 2020 concerning Job Creation. According to the website of the Investment Coordinating Board's OSS Institution, there are two codes relating to the convection business in the 2017 Indonesian Standard Classification of Business Fields ("KBLI"). Garment Industry (Convection) from Textiles (KBLI Code 14111). This category encompasses the business of cutting and stitching finished garments (convection) from textiles/fabric (woven and knitted), such as shirts, slacks, kebaya, blouses, skirts, baby clothes, dance clothes, and sports clothes, from woven and knitted materials. Leather Apparel (Convection) Industry, KBLI Code 14112. This category comprises the business of cutting and sewing leather or imitation leather items, such as jackets, coats, vests, pants, and skirts, so that they are ready to wear. This involves producing leather garment items like welder's leather aprons and leather welding gear. A legal entity is not just a commercial requirement; it is also a chance for enterprises to carry out projects for large corporations and governments, therefore having a legal entity allows a distribution company to expand its target market to huge corporations and governments.

\section{Porter Five Forces}

\section{Competitive Rivalry (High)}

The competitive rivalry within the industry of clothing convection is considered as high. In Jawa Barat, from the website of Kementerian Perindustrian, there are 198 clothing convection that already registered in Kementerian Perindustrian, and 116 of them are located in Bandung. And there are more that are still not registered in the Kementerian Perindustrian. The product differentiation in the clothing convection industry is also considered as low. Therefore, the industry is having highly competitive rivalry.

\section{Bargaining Power of Suppliers (Low)}

The bargaining power of suppliers in the industry of clothing convection is considered as low. In Jawa Barat, from the website of Kementerian Perindustrian, there are 221 textile companies that registered. It means that there are many options of suppliers in the industry, so the ability to switch among the suppliers is considered as high. The product differentiation of suppliers is also considered as low because there is no significant difference between the products of suppliers. Therefore, the clothing convection industry has low bargaining power for suppliers. 


\section{Bargaining Power of Buyers (High)}

The bargaining power of buyers in the clothing convection industry is considered as high. Because there are a lot of competitors in the industry and the product is also not significantly differentiated, it might be differentiated by the service the company offers. The price is also the important factor for the customers to choose the clothing convection, and they can look out through the internet to consider the price between clothing convection. Therefore, the clothing convection industry has a high bargaining power of buyers.

\section{Threat of Substitutes Product (Medium)}

The threat of substitutes product in the industry of clothing convection is considered as medium. In clothing convection, it has the substitute of buying the finished product of apparel, but it cannot be customized such as making in the clothing convection, and usually the price is considered higher than making in the clothing convection. Therefore, the clothing convection industry has a medium threat of substitutes products.

\section{Threat of New Entrants (Medium)}

Threat of New Entrants in the clothing convection industry is considered as medium. The capital requirement of making clothing convection is medium. The clothing convention also needs a legality to make business with other companies, because to register a tender for a project of making apparel for other companies, we need legality to register. And also, to be a new clothing convection, we have to compete with other clothing convection that already has loyal customers and awareness from the society.

\section{SWOT Analysis}

The analysis of SWOT shows that the company has several strengths, including the value Raiment wants to give to the customers and technology element that Raiment develops. The company also has several weaknesses, such as the production process that we still outsourced, the lack of product knowledge, and limited capital. Raiment has opportunities from the good prospect of the industry that is always growing before pandemics, the industry is one of the focuses of the government in Making Indonesia 4.0 and changing behaviour of online buying that give Raiment opportunity. Besides that, there are already many players in the industry and because of the covid-19 pandemic, there is a changing consumption tendency of the society focusing on health and food ingredients.

Table 1: SWOT Analysis

\begin{tabular}{|c|c|}
\hline $\begin{array}{l}\text { Strength } \\
\text { - The value offered by Raiment to } \\
\text { give ease to find through online } \\
\text { platforms and trust with progress } \\
\text { tracking. } \\
\text { - Using technological elements } \\
\text { (website and social media) in selling } \\
\text { products to make the market wider } \\
\text { (not only in the area of production of } \\
\text { Raiment). }\end{array}$ & $\begin{array}{l}\text { Weakness } \\
\text { - Still outsourcing the production process } \\
\text { (haven't had our own production machine). } \\
\text { - Lack of knowledge in the product. } \\
\text { - Limited financial capital }\end{array}$ \\
\hline $\begin{array}{l}\text { Opportunity } \\
\text { - The positive growth of the textile } \\
\text { and clothing industry shows good } \\
\text { prospects in the industry. } \\
\text { - The support for the textile and } \\
\text { clothing industry from the } \\
\text { government of implementing }\end{array}$ & $\begin{array}{l}\text { Threat } \\
\text { - Have many competitors in the clothing } \\
\text { convection industry. } \\
\text { - Changing consumption patterns in the } \\
\text { pandemic to focus on health and food } \\
\text { ingredients. }\end{array}$ \\
\hline
\end{tabular}


Making Indonesia 4.0.

- In this pandemic people tend to buy products online and Raiment already develops online platforms.

\section{Fishbone Diagram}

The fishbone diagram will be explaining the problem of Raiment. The problem will be analysed by the category of finance, operation, human resource, and marketing.

Figure 3: Fishbone Diagram

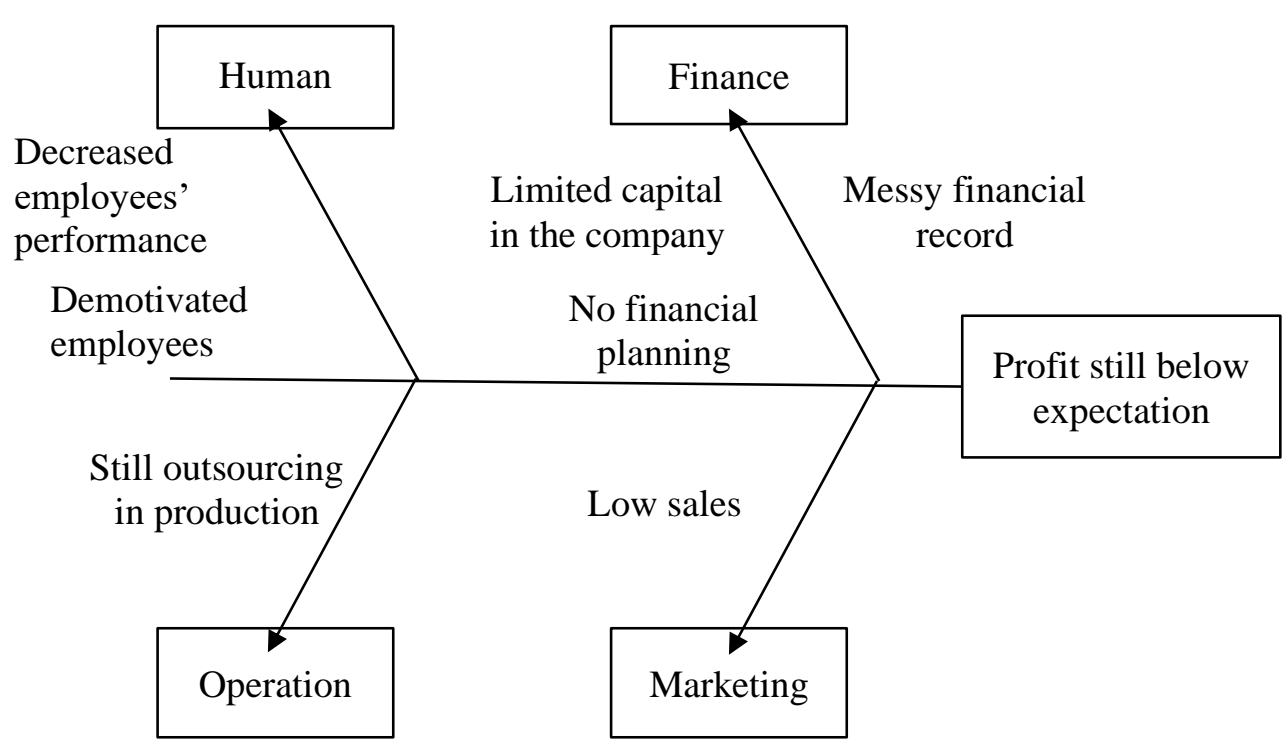

\section{Root Cause Statement}

It can be seen from the fishbone diagram that one of the problems in human resources is decreasing employee performance, this happens due to lack of motivation of the employees. It affected the running of the business of Raiment. In the marketing sector, Raiment couldn't reach out to the market to have significant sales, and it didn't meet the expectations about the sales from the company. And in the financial sectors, the profit in the company is below the expectations. One of the factors in finance from the problem in finance is the lack of knowledge from financial officers of Raiment in finance and to hire finance people is considerably expensive, and it affects the important factor in finance that is the lack of management of the company. The company hasn't had financial planning to spend the expense and have a target on sales. Inability to manage finances inside the organization indicates that the company is experiencing poor financial performance. With the profit still below the expectations, Raiment's founders have a strategy to give capital to the company on buying a production machine and have their own production house. And it is a problem in the operation sector, so we still depend on our partner for the entire production process. We also still have a low profit margin because we still must adjust the price that we get from partners to the market price.

\section{Business Solution Alternatives}

The researcher will go through each component of the data analysis in detail in this phase, including scenario analysis, which will define all the assumptions applied and examine the outcomes of the cash flow projection and capital budgeting analysis. In making the financial projection, the researcher will use scenario analysis with three scenarios including best-case, base case, and worst-case. To assess the total 
company's financial activity, the financial projection will combine the revenues and expenses of Raiment's company activity.

\section{Base-Case Scenario Assumptions}

The projection assumption is used to calculate the financial projection of the Raiment company. The assumptions are based on benchmarking to the competitors. The revenue projections are based on the competitors first year of establishment, because currently it is still in pandemic, so we adapt the revenue to the competitor's condition in pandemic. The cost of goods sold is based on the price of raw materials and production processes, based on the benchmark to competitors. The expenses are calculated based on the benchmarking of the competitors and searching through an online marketplace.

Table 2: Projection Assumptions

\begin{tabular}{|c|c|c|c|c|c|}
\hline \multicolumn{6}{|c|}{ Projection Assumptions } \\
\hline \multicolumn{6}{|l|}{ Revenue } \\
\hline Revenue calculation base & \multicolumn{5}{|c|}{ Competitor revenue from 2016 until 2020} \\
\hline Revenue in 2022 & \multicolumn{5}{|c|}{$\begin{array}{l}\text { The revenue calculation is based on the revenue of competitors } \\
\text { in the first year established and adapted to their current sales in } \\
\text { pandemic. }\end{array}$} \\
\hline & S & M & $\mathrm{L}$ & XL & XXL \\
\hline Ratio of the size to sales & $25 \%$ & $35 \%$ & $25 \%$ & $14 \%$ & $1 \%$ \\
\hline Monthly sales growth & \multicolumn{5}{|c|}{$\begin{array}{l}\text { The monthly sales growth is based on benchmarking the cycle } \\
\text { of sales of competitors based on sales data and interview }\end{array}$} \\
\hline Annual sales growth & \multicolumn{5}{|c|}{$35 \%$} \\
\hline Cost of goods sold growth & \multicolumn{5}{|c|}{ Based on the data of the increasing price of cost of goods sold } \\
\hline & $S$ & M & $\mathrm{L}$ & $\mathrm{XL}$ & XXL \\
\hline Cost of goods sold & Rp28,758 & Rp32,528 & $\operatorname{Rp} 38,085$ & $\mathrm{Rp} 47,316$ & Rp65,715 \\
\hline \multicolumn{6}{|l|}{ Expenses } \\
\hline Marketing Expenses & \multicolumn{5}{|c|}{$\begin{array}{l}\text { The marketing team offers the marketing expenses is for } \% 5 \text { of } \\
\text { revenue }\end{array}$} \\
\hline Salary Expense & \multicolumn{5}{|c|}{ Salary expense is $\mathrm{Rp} 4,000,000$} \\
\hline Rent Expense & \multicolumn{5}{|c|}{$\begin{array}{l}\text { Rent expense for production house in Bandung is } \\
\text { Rp35,000,000 with the size of building area for } 130 \mathrm{~m} 2\end{array}$} \\
\hline Website Maintenance Expense & \multicolumn{5}{|c|}{$\begin{array}{l}\text { To maintain the website, based on the interview have cost for } \\
\text { Rp2,000,000 per year }\end{array}$} \\
\hline Website Hosting Expenses & \multicolumn{5}{|c|}{$\begin{array}{l}\text { Website hosting expenses is from the historical data of the } \\
\text { company that cost Rp } 198,000 \text { per year }\end{array}$} \\
\hline
\end{tabular}




\begin{tabular}{|c|c|}
\hline \multicolumn{2}{|r|}{ Projection Assumptions } \\
\hline Transport Expenses & $\begin{array}{l}\text { Purchase of raw materials weekly using a pickup truck service } \\
\text { for Rp } 100,000\end{array}$ \\
\hline \multicolumn{2}{|l|}{ Utility Expense } \\
\hline Electricity and water & $\begin{array}{l}\text { Electricity and water expenses based on the interview of } \\
\text { clothing convection company with same amount of equipment } \\
\text { for Rp700,000 }\end{array}$ \\
\hline Maintenance Expense & $\begin{array}{l}\text { Cost of maintenance per machine is Rp600,000 per } 6 \text { months } \\
\text { for } 5 \text { machines }\end{array}$ \\
\hline \multicolumn{2}{|l|}{ Depreciation Expense } \\
\hline Cutting Machine (1) & $\begin{array}{l}\text { Price: Rp545,000, } 4 \text { years depreciation cost assessment as } \\
\text { specified in Ministry of Finance Regulation No. } \\
\text { 96/PMK.03/2009 }\end{array}$ \\
\hline Screen Printing Table (3) & $\begin{array}{l}\text { Price: Rp9,000,000 for } 3 \text { pcs, } 4 \text { years depreciation cost } \\
\text { assessment as specified in Ministry of Finance Regulation No. } \\
\text { 96/PMK.03/2009 }\end{array}$ \\
\hline Screen Printing Film Tool (1) & $\begin{array}{l}\text { Price: Rp1,950,000,4 years depreciation cost assessment as } \\
\text { specified in Ministry of Finance Regulation No. } \\
\text { 96/PMK.03/2009 }\end{array}$ \\
\hline Screen Printing Curing Tool (1) & $\begin{array}{l}\text { Price: Rp1,025,000, } 4 \text { years depreciation cost assessment as } \\
\text { specified in Ministry of Finance Regulation No. } \\
\text { 96/PMK.03/2009 }\end{array}$ \\
\hline Screen $(8)$ & $\begin{array}{l}\text { Price: Rp240,000, } 4 \text { years depreciation cost assessment as } \\
\text { specified in Ministry of Finance Regulation No. } \\
\text { 96/PMK.03/2009 }\end{array}$ \\
\hline Water Gun (1) & $\begin{array}{l}\text { Price: Rp360,000, } 4 \text { years depreciation cost assessment as } \\
\text { specified in Ministry of Finance Regulation No. } \\
\text { 96/PMK.03/2009 }\end{array}$ \\
\hline Press Machine (1) & $\begin{array}{l}\text { Price: Rp1,820,000, } 8 \text { years depreciation cost assessment as } \\
\text { specified in Ministry of Finance Regulation No. } \\
\text { 96/PMK.03/2009 }\end{array}$ \\
\hline Chain Sewing Machine (1) & $\begin{array}{l}\text { Price: Rp3,990,000, } 8 \text { years depreciation cost assessment as } \\
\text { specified in Ministry of Finance Regulation No. } \\
\text { 96/PMK.03/2009 }\end{array}$ \\
\hline Single Sewing Machine (1) & $\begin{array}{l}\text { Price: Rp2,990,000, } 8 \text { years depreciation cost assessment as } \\
\text { specified in Ministry of Finance Regulation No. } \\
\text { 96/PMK.03/2009 }\end{array}$ \\
\hline Overdeck Sewing Machine (1) & $\begin{array}{l}\text { Price: Rp5,500,000, } 8 \text { years depreciation cost assessment as } \\
\text { specified in Ministry of Finance Regulation No. } \\
\text { 96/PMK.03/2009 }\end{array}$ \\
\hline Obras Sewing Machine (1) & $\begin{array}{l}\text { Price: Rp3,900,000, } 8 \text { years depreciation cost assessment as } \\
\text { specified in Ministry of Finance Regulation No. } \\
\text { 96/PMK.03/2009 }\end{array}$ \\
\hline
\end{tabular}


DOI: https://doi.org/10.47405/mjssh.v6i9.1018

\begin{tabular}{|l|l|}
\hline & Projection Assumptions \\
\hline Tax Expense & $\begin{array}{l}\text { The MSME tax rate is } 0.5 \% \text { of turnover provided that the } \\
\text { turnover for one year is not more than } 4.8 \text { billion }\end{array}$ \\
\hline
\end{tabular}

\section{Best-Case and Worst-Case Scenario Assumptions}

The projection assumption is used to calculate the financial projection in the best-case and worst-case scenarios for Raiment company. The sales quantity above is used for each scenario of the sales quantity of the base case. The base case sales quantity is from the benchmarking of the competitor's first establishment and due to the current condition of the pandemic, it adapted to the competitor's sales quantity in the pandemic. And the difference between the best-case and worst-case scenario is for 25 percent less and 25 percent more.

Table 3: Projection Assumptions

\begin{tabular}{cccc}
\hline \multicolumn{4}{c}{ Projection Assumptions } \\
\hline Scenario & Best-Case & Base-Case & Worst-Case \\
\hline Sales Quantity & $125 \%$ of Base Case & $6500 \mathrm{pcs}$ & $75 \%$ of Base Case \\
\hline
\end{tabular}

\section{Cash Flow Projection}

The initial investment is fully financed by paid-in capital from the founders. The needs of capital expenditures in the investment are listed in the table above, and it applies to all scenarios from best-case, base-case, and worst-case.

Table 4: Initial Investment

\begin{tabular}{lr}
\hline & Initial Investment \\
Capital Expenditure & \\
Equipment & Price \\
\hline Cutting Machine (1) & $\mathrm{Rp} 545,000$ \\
Screen Printing Table (3) & $\mathrm{Rp} 9,000,000$ \\
Screen Printing Film Tool (1) & $\mathrm{Rp} 1,950,000$ \\
Screen Printing Curing Tool (1) & $\mathrm{Rp} 1,025,000$ \\
Screen (8) & $\mathrm{Rp} 240,000$ \\
Water Gun (1) & $\mathrm{Rp} 360,000$ \\
Press Machine (1) & $\mathrm{Rp} 1,820,000$ \\
Chain Sewing Machine (1) & $\mathrm{Rp} 3,990,000$ \\
Single Sewing Machine (1) & $\mathrm{Rp} 2,990,000$ \\
Overdeck Sewing Machine (1) & $\mathrm{Rp5}, 500,000$ \\
Obras Sewing Machine (1) & $\mathrm{Rp3,900,000}$ \\
Rent & $\mathrm{Rp35,000,000}$ \\
Total Initial Investment & $\mathrm{Rp66,320,000}$ \\
\hline
\end{tabular}


Table 5: Cash Flow Projection

\begin{tabular}{crrr}
\hline \multicolumn{4}{c}{ Cash Flow Projection } \\
Year & \multicolumn{1}{c}{ Best-Case } & \multicolumn{1}{c}{ Base-Case } & \multicolumn{1}{c}{ Worst-Case } \\
\hline Initial Investment & \multicolumn{1}{c}{ Rp66,500,000) } & $($ Rp66,500,000) & $($ Rp66,500,000) \\
2022 & $\mathrm{Rp} 8,895,552$ & $-\mathrm{Rp} 26,174,420$ & $-\mathrm{Rp} 61,244,392$ \\
2023 & $\mathrm{Rp} 116,660,120$ & $\mathrm{Rp} 40,036,037$ & $-\mathrm{Rp} 36,588,047$ \\
2024 & $\mathrm{Rp} 258,006,027$ & $\mathrm{Rp} 133,100,867$ & $\mathrm{Rp} 8,195,706$ \\
2025 & $\mathrm{Rp} 417,903,886$ & $\mathrm{Rp} 238,372,186$ & $\mathrm{Rp58,840,486}$ \\
2026 & $\mathrm{Rp} 615,228,718$ & $\mathrm{Rp} 376,197,624$ & $\mathrm{Rp} 137,166,530$ \\
\hline
\end{tabular}

In the table above are the results of cash flow projections. After constructing yearly financial statements, cash flow estimates are produced. The estimate is based on the investment lifetime of 5 years that has been determined. After conducting cash flow projections, capital budgeting analysis will be utilized.

\section{Capital Budgeting Analysis}

The capital asset pricing model calculated by beta, market return, and risk-free rate to conduct the cost of equity. The beta that was used is based on the similar business of textile and garment industry. The market return is based on the Composite Stock Price Index (IHSG). The risk-free rate is from the BI 7day Repo Rate of 3.5 percent. The beta, market return, and risk-free rate calculated into cost of equity for 4.18 percent.

Table 6: Capital Asset Pricing Model

\begin{tabular}{lc}
\hline & Capital Asset Pricing Model \\
\hline Beta & 0.08 \\
Market Return & $11.96 \%$ \\
Risk-free Rate & $3.5 \%$ \\
Cost of Equity & $4.18 \%$ \\
\hline
\end{tabular}

In the capital budgeting analysis, there are some criteria for accepting investment. For the NPV, it must be greater than 0 , so when it's not greater than 0 or even negative, it won't be acceptable. In the table above, all the three scenarios are greater than 0 , so it is acceptable. For the IRR it is based on the cost of capital, so it must be greater than $4,18 \%$ to be acceptable. For the payback period, it must be more than 5 years to accept, all the scenarios have a payback period below 5 years, so all the payback periods are acceptable. All the scenarios are acceptable because all the scenarios are all above the criteria.

Table 7: Capital Budgeting Analysis

\begin{tabular}{lcccc}
\hline \multicolumn{4}{c}{ Capital Budgeting Analysis } \\
& Criteria & Best-Case & Base Case & Worst-Case \\
\hline Net Present Value & $>0$ & Rp385,744,245 & Rp235,260,441 & Rp $84,776,637$ \\
Internal Rate of Return & $>4.18 \%$ & $142.13 \%$ & $90.33 \%$ & $36.08 \%$ \\
Payback Period & $<5$ years & 0.88 years & 1.4 years & 2.8 years \\
\multicolumn{1}{c}{ Investment Approval } & Acceptable & Acceptable & Acceptable \\
\hline
\end{tabular}




\section{Discussion}

The cost of capital is calculated using the cost of equity because Raiment company only used equity and didn't use debt in fulfilling its initial investment, and the cost of capital is for $4.18 \%$. For initial investment of Rp66,500,000, the best-case scenario generates an NPV of Rp385,744,245, IRR for $142.13 \%$, and payback period for 0.88 years. The base-case generates an NPV of Rp235,260,441, IRR for $90.33 \%$, and payback period for 1.4 years. The worst-case scenario generates an NPV of Rp84,776,637, IRR for $36.08 \%$, and payback period for 2.8 years.

\section{Conclusion}

Raiment is a clothing convection company that offers services for making apparel through an onlinebased platform. The company currently outsourced its production, so the company didn't have their own production machine and depends on other companies to produce the product and focus on reaching customers and developing websites. The company planned to build its own production house and own its production machine. This study aims to find out whether the plan of Raiment is feasible or not. The data collected is from primary and secondary data, the primary data from historical data of Raiment and interviews with clothing convection owners, and the secondary data for additional assumptions. The researcher also conducts current business analysis. The feasibility of the strategies of Raiment analyzed with capital budgeting analysis.

From the capital budgeting analysis, the net present value, internal rate of return, and payback period of all scenarios are acceptable. So, the strategy of Raiment in making the company's own production machine and their own production house is feasible.

The financial side of Raiment company's plan to make their own production house and buy their own machine is examined in this paper. This research uses three different scenarios to differentiate the condition that faced by the company. The scenario made to minimize the risk that can be faced by the company through unpredictable market condition, problem faced, or change of consumption behavior of the customers. This research can be utilized for further analysis of Raiment's financial divisions. The strategy's other aspects, such as selection of location and research of market, will require further research. As a result, the best possible outcomes will be attained, and errors will be reduced to the absolute minimum.

\section{References}

Adwiyah, R., Cintyawati, C., Firmansyah, F., Mustikawati, F., Fatimah, S., \& Islami, V. (2020). Boosting the Performance of Convection Creative Industry Through Supply Chain Management and Brand Image Enhancement. https://doi.org/10.2991/assehr.k.200225.132

Amanor-Boadu, V. (2003). Assessing the Feasibility of Business Propositions.

Auken, H. V., \& Carraher, S. (2013). Influences on Frequency of Preparation ofFinancial Statements Among SMEs.Bank Indonesia. (2015). Profil Bisnis Usaha Mikro, Kecil, dan Menengah (UMKM).

Dunska, M., \& Marcinkevica, A. (2017). Situation and Development Opportunities of Creative Industries Companies in Latvia. European Research Studies Journal, Volume XX, Issue 3A, 96114, 2017. DOI: $10.35808 / \mathrm{ersj} / 698$

European Parliament. (2021). The Impact of Textile Production and Waste on The Environment. https://www.europarl.europa.eu/news/en/headlines/society/20201208STO93327/the-impact-oftextile-production-and-waste-on-the-environment-infographic

Fight, A. (2006). Cash Flow Forecasting. Oxford.

Fitriani, R. (2017). Aspek Hukum Legalitas Perusahaan atau Badan Usaha dalam Kegiatan Bisnis.

Gitman, L. J., \& Zutter, C. J. (2015). Principles of Managerial Finance (14th ed.). Harlow: Pearson. 
DOI: https://doi.org/10.47405/mjssh.v6i9.1018

Hidayat, A. R. T., \& Asmara, A. Y. (2017). Creative industry in supporting economy growth in Indonesia: Perspective of regional innovation system. PersIOP Conference Series: Earth and Environmental Science, 70, 012031. doi:10.1088/1755-1315/70/1/012031

Hox, J. J., \& Boeije, H. R. (2005). Data Collection, Primary vs. Secondary.

Kementerian Perindustrian Republik Indonesia. (2018). www.kemenperin.go.id

McKinsey Company. (2018). The State of Fashion 2018.

McKinsey Company. (2021). The State of Fashion 2021.

Miller, J., Boumtje, P., \& Johnson, R. (2017). Investment Analysis for Commercial Greenhouse Hydroponically Produced Lettuce and Tomato. Journal of ASFMRA (2017).

Samonas, M. (2015). Financial Forecasting, Analysis, and Modelling : A Framework for Long-Term Forecasting. John Wiley \& Sons Ltd.

Sugih, I. L., \& Soekarno, S. (2014). Lesson Learned from Indonesian Biggest Fashion Retailer Company to Encourage the Development of Small Fashion Business. The 6th Indonesia International Conference on Innovation, Entrepreneurship and Small Business. https://doi.org/10.1016/j.sbspro.2015.01.307

Weygandt, J. J., Kimmel, P. D., \& Kieso, D. E. (2013). Financial Accounting IFRS (2e ed.). John Wiley \& Sons Ltd.

Zakkariya, K. A., \& Nishanth, P. (2014). Barriers Faced by Micro, Small and Medium Enterprises in Raising Finance. 